\title{
ONCHOCERCA EBERHARDI N. SP. (NemATOdA: Filarioidea) FROM SIKA DEER IN JAPAN; RELATIONSHIPS BETWEEN SPECIES PARASITIC IN CERVIDS AND BOVIDS IN THE HOLARCTIC REGION
}

\author{
UNI S.****, BAIN O.**, AGATSUMA T.***, HARADA M.*****, TORII H.******, FUKUDA M.******* \& TAKAOKA H.********
}

\section{Summary :}

Onchocerca eberhardi n. sp. from the sika deer, Cervus nippon, in Japan is described. Adult worms lived in the carpal ligament; infection reached high levels (up to 25 female and 16 male worms in a single carpal limb). Skin dwelling microfilariae were mainly found in the ears. Prevalence of infection was $81 \%$ at the type locality, Mt. Sobo, in Kyushu. The new material was compared to the 31 species of Onchocerca presently known. Onchocerca eberhardi n. sp. females were characterized by a long slender anterior end and a thin esophagus $\leq 1 \mathrm{~mm}$ long with no or only a slight glandular region. The vulva was located near the level of the mid-esophagus and the cuticle had transverse external ridges and internal striae (two striae between adjoining ridges). The most similar species were $O$. stilesi (re-examined), $\bigcirc$. lienalis, and to a lesser extent $\bigcirc$. gutturosa, all from bovids (cattle). Two main lineages of Onchocerca are recognized in cervids with either primitive or with derived characteristics (as exemplified by the new species). The species in both lineages are not restricted to cervids but are also found in bovids in the Holarctic region, suggesting that the species diversified in the two host groups simultaneously, when these host groups lived in the same geographic area.

KEY WORDS : Filarioid, Onchocerca eberhardi n. sp., Cervus nippon, sika deer, carpal ligament, Japan, Onchocerca stilesi, Bovidae, Holarctic region.

\section{INTRODUCTION}

U ntil recently, Onchocerca species known in Japan were only those species from cosmopolitan domesticated animals: in horses O. cervi-

\footnotetext{
* Department of Medical Zoology, Osaka City University Medical School, Osaka 545-8585, Japan.

* Parasitologie comparée et Modèles expérimentaux, USM 307, Muséum National d'Histoire Naturelle, Paris, France.

**** Department of Environmental Health Science, Faculty of Medicine, Kochi University, Nankoku, Kochi, Japan.

***** Laboratory Animal Center, Osaka City University Medical School, Osaka, Japan.

**:**** Education Center for Natural Environment, Nara University of Education, Nara, Japan.

*:***:** Department of Infectious Disease Control, Faculty of Medicine, and Division of Epidemiology, Culture, and Communication, Institute of Scientific Research, Oita University, Oita, Japan.

*****:*** Department of Infectious Disease Control, Faculty of Medicine, Oita University, Oita, Japan.

Correspondence: Shigehiko Uni.

Tel.: + 81666453760 - Fax: + 81666453762

E-mail: uni@med.osaka-cu.ac.jp
}

Résumé : ONCHOCERCA EBERHARDI N. SP. (Filarioidea, NeMATODA) CHEZ LE CERF SIKA AU JAPON; RELATIONS ENTRE LES ONCHOCERQUES DE Cervidae et de Bovidae en région holarctique

Description d'Onchocerca eberhardi n. sp., parasite de Cervus nippon, au Japon. Les adultes vivent dans le ligament carpal; l'infection peut être forte (un cas avec 25 femelles et 16 mâles) La localisation principale des microfilaires dermiques est le lobe des oreilles. La prévalence est de 81 \% dans la localité-type, Mont Sobo, Kyushu. Le nouveau matériel est comparé aux 31 espèces décrites dans le genre. L'espèce est distincte par plusieurs caractères de la femelle, oesophage fin, $\leq 1 \mathrm{~mm}$ de long, avec une partie glandulaire faiblement différenciée ou non distincte, la vulve assez antérieure, la cuticule ornée de côtes et de stries (deux stries par intercôtes). Les espèces les plus proches sont $\bigcirc$. stilesi (réétudié ici), $\bigcirc$. lienalis et, à un moindre degré, O. gutturosa, toutes parasites de Bovidae (bétail). Deux principales lignées sont reconnues chez les onchocerques de Cervidae, respectivement avec des caractères primitifs ou évolvés (cas de la nouvelle espèce). Dans les deux lignées, les représentants ne sont pas restreints aux Cervidae et se trouvent aussi chez des Bovidae, en région holarctique, suggérant qu'ils se sont diversifiés simultanément chez les deux groupes d'hôtes quand ceux-ci étaient dans la même région géographique.

MOTS CLÉS : Filaire, Onchocerca eberhardi n. sp., Cervus nippon, cerf sika, ligament carpal, Japon, Onchocerca stilesi, Bovidae, région holarctique. 
nica Uni, Bain \& Takaoka, 2001 is a parasite of the wild boar in Kyushu, the large southern island of Japan. Unexpectedly, this species appeared to be locally an agent of zoonotic onchocerciasis (Takaoka et al., 2001, 2004, and 2005), whereas in other parts of the world species of Onchocerca from cattle or horses are generally identified or suspected in zoonotic onchocerciasis (Engelkirk et al., 1982; Orihel \& Eberhard, 1998).

The new Onchocerca species described here is a parasite of the sika deer in Kyushu and resembles some parasites of cattle, particularly O. stilesi Eberhard, 1979, a rare species from the United States, which we have examined here to specify precise morphologic characteristics for diagnosis.

\section{MATERIALS AND METHODS}

T The host animals examined for species of Onchocerca were sika deer (Cervus nippon Temminck) from Kyushu. Fifty-four sika deer living on Mt. Sobo, Oita Prefecture, and nine sika in Kumamoto Prefecture were killed between September 1998 and February 2006 in accordance with the conservation and control policies of the Ministry of the Environment, Japan. The head, the entire skin of the body, and the limbs were shipped refrigerated to a laboratory for filarial examination one or two days after the animals were killed.

For the detection of adult worms, subcutaneous connective tissues and the ligaments of joints of the limbs were inspected under a stereomicroscope. In addition, we used the collagenase technique (Schulz-Key, 1988) to obtain complete adult parasites in the joints of six sika deer, because the Onchocerca adults lived deep inside the ligaments: the carpal or tarsal joints were incubated in saline solution containing $0.3-0.5 \%$ collagenase type I (Worthington Biochemical Corporation, New Jersey) for 8 to $24 \mathrm{~h}$ at $38^{\circ} \mathrm{C}$.

For the detection of microfilariae, skin snips were taken from the face, ears, neck, back, limbs, and tail of each animal by the methods described by Uni et al. (2002). Microfilariae that came out were examined for identification and compared to microfilariae extracted from the ovejector of female worms. The latter microfilariae were stained with Giemsa's solution. In addition, blood films were made from each deer and stained with Giemsa's solution. The eyeballs of the sika deer (ID nos. S28, S30-34) were dissected under a stereomicroscope to examine the cornea and retina for lesions.

To investigate the co-existence of filarial parasites in sika deer, other species of filarioids [Cercopithifilaria crassa Uni \& Bain, 2002, C. longa Uni \& Bain 2002, Mansonella (Cutifilaria) perforata Uni, Bain \& Takaoka,
2004, and O. skrjabini] were sought in skin snips for microfilariae and in skin and limbs by dissection under a stereomicroscope for adult worms (Uni et al., 2002, 2004).

Adult worms detected were placed in $2 \%$ formalin in saline solution and the specimens were cleared in lactophenol for study. For histologic examination, the carpal lesions infected with the parasites were embedded with paraffin by routine methods and the sections were stained with hematoxylin and eosin. Scanning electron microscopic (SEM) micrographs of the females and males were prepared as described elsewhere (Uni et al., 2001).

Measurements are given in Tables I and II: the body length of adult worms in millimeters and the other dimensions in micrometers. In females, characteristics of the external cuticular ridges and number of internal striae are described; in this study, following Railliet \& Henry (1910), "striae" means the furrows or lines, as in Bain \& Schulz-Key (1974), not the thick part of the cuticle demarcated between two consecutive furrows, as in Beaver et al. $(1974,1983)$. This precision is important as the number of striae between two adjoining ridges (striae/inter-ridge) is a distinctive characteristic. In the male, the caudal pairs of papillae are tentatively numbered on the basis of a set of 10 pairs, as in Chabaud \& Petter (1961) for spirurids and Bain et al. (1976) for a primitive species of Onchocerca. The authorities of the new species are Uni and Bain.

Two specimens of O. stilesi Eberhard, 1979 from Minnesota, U.S.A., were examined: the female holotype, USNM Helminth collection No. 75108 and a male paratype, USNM Helminth collection No. 75109. The host was Bos taurus; the habitat, connective tissues around the stifle joint.

\section{RESULTS}

ONCHOCERCA EBERHARDI UNI \& BAIN, N. SP. (Tables I-III; Figs 1, 2, 4-16)

Filarioidea, Onchocercidae (Leiper, 1911) Chabaud \& Anderson, 1959, Onchocercinae Leiper, 1911, Onchocerca (Diesing, 1841) Railliet \& Henry, 1910.

Adult worms loosely coiled in the carpal ligament. The specimens recovered were abundant: one complete female and 139 female fragments ( 74 anterior, 31 midbody, and 34 posterior parts); 47 complete males and 24 male fragments (nine anterior, seven midbody, and eight posterior parts).

- Female (one complete, 10 anterior, and 10 posterior parts): very thin and straight anterior end $3 \mathrm{~mm}$ long. Slight cervical swelling posterior to nerve ring (Fig. 1A). Head: external labial papillae arranged in a rectangle elongated dorsoventrally; cephalic papillae arranged in 


\begin{tabular}{|c|c|c|c|c|}
\hline & O. eberbardi n. sp. & O. stilesi ${ }^{1}$ & O. lienalis $^{2}$ & O. gutturosa $a^{3}$ \\
\hline Female & S59-C36 $(n=10)$ & & & \\
\hline Body length & 175 & ND & 316 & ND \\
\hline Body width & $230(170-230)[207]$ & $140-220(180)$ & $180-220$ & $140-225$ \\
\hline Body width at end of esophagus & $70(51-70)[60]$ & $55^{* *}$ & 50 & $75-80$ \\
\hline Nerve ring* & $190(170-235)[192]$ & $120-180(140), 180^{* * *}$ & 210 & $200-260$ \\
\hline Cervical swelling & Yes (slight swelling) & Yes $^{* *}$ & No & Yes \\
\hline Vulva* & $480(425-620)[508]$ & $360-740(440)$ & $543-560$ & 480-640 \\
\hline Glandular esophagus & ND (610-795) [685] & $370-630(480)$ & $525-770$ & Not divided \\
\hline Esophagus & $980(880-1,080)[975]$ & $540-910(730)$ & $865-1,195$ & $1,000-1,210$ \\
\hline Cuticle thickness & $30(28-32)$ & $16-18^{* * *}$ & $12-17$ & $25-50$ \\
\hline Cuticle surface & Smooth & Wrinkled*** & Longitudinal wrinkles & Smooth \\
\hline Number of striae between ridges & 2 & 3 & 2 & $4-7$ \\
\hline Ridge shape & Straight & Undulated** & Undulated & Undulated \\
\hline Branching of ridges at lateral field & No & Yes, $\left(\mathrm{NO}^{* *}\right)$ & Yes & Yes \\
\hline Cuticular thickening at lateral fields & No & $\mathrm{No}^{* * *}$ & No & Yes \\
\hline 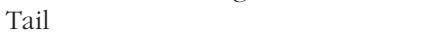 & $150(115-150)[135]$ & $60-120(80)$ & $150-228$ & $140-170$ \\
\hline Microfilariae & $(\mathrm{n}=20)$ & $(\mathrm{n}=5)^{* *}$ & & \\
\hline Body length & ND (200-258) [235] & $177-190^{* *}$ & $225-260$ & $260-280$ \\
\hline Body width & ND $(4-5)[5]$ & $4-5^{* * *}$ & $5.0-5.3$ & 5 \\
\hline
\end{tabular}

Holotype (S59-C36) of O. eberhardi n. sp. is presented first, followed by range and then mean. Unit: See text. * From anterior end. n: Number of parasites examined. ND: Not done. References: ${ }^{1}$ Eberhard, 1979, **Present study, ${ }^{2}$ Bain et al., 1978b and ${ }^{3}$ Bain, 1975.

Table I. - Measurements of females and microfilariae of Onchocerca eberhardi $\mathrm{n}$. sp. from sika deer and closely related species from bovids.

\begin{tabular}{|c|c|c|c|c|}
\hline & O. eberhardi n. sp. & O. stilesi ${ }^{1}$ & O. lienalis $^{1}$ & O. gutturosa $a^{2}$ \\
\hline Male & S59-C38 $(n=10)$ & & & \\
\hline Body length & $22(17-26)[21]$ & $19-28$ & $18.5-24.5$ & $22.8-33.4$ \\
\hline Body width & $65(50-68)[58]$ & $55-80(70)$ & $50-80$ & $85-90$ \\
\hline Nerve ring* & $178(163-205)[186]$ & $100-150(120)$ & $110-170$ & 250 \\
\hline Glandular esophagus & $493(493-565)[541]$ & $270-480(380)$ & - & - \\
\hline Esophagus & $780(690-870)[785]$ & $470-720(580)$ & $590-800$ & $880-970$ \\
\hline Right spicule & $60(60-70)[66]$ & $50-70(60)$ & $60-80$ & 85 \\
\hline Left spicule & $208(185-223)[200]$ & $150-200(170)$ & $190-230$ & $270-290$ \\
\hline Pairs of caudal papillae & $8(7-9)$ & $8-9$ & 7 & 7 \\
\hline Tail & $60(50-83)[63]$ & $50-70(60)$ & $55-80$ & $105-115$ \\
\hline Host animal(s) & Cervus nippon & Bos taurus & Bovids, Bos taurus & B. taurus, B. indicus \\
\hline Parasitic location & Carpal ligament & Connective tissues around stifle joint & Gastrosplenic ligament & Nuchal ligament \\
\hline Locality & Japan & USA & USA, France & West Africa \\
\hline
\end{tabular}

Allotype (S59-C38) of O. eberhardi n. sp. is presented first, followed by range and then mean. Unit: See text. * From anterior end. n: Number of parasites examined. - Not reported. References: ${ }^{1}$ Eberhard, 1979 and ${ }^{2}$ Bain, 1975.

Table II. - Measurements of males, hosts, parasitic locations, and localities of Onchocerca eberhardi n. sp. from sika deer and closely related species from bovids.

a rectangle elongated laterally (Figs 1B-D and 13, arrows). Buccal capsule absent but very thin cuticular plate present; lumen at base of buccal cavity Y-shaped in transverse section. Esophagus thin, with no distinct or with slightly granulous glandular part. Body width narrow at posterior end of esophagus (Table I). Vulva near midlength of esophagus; its distance to head two to three times the distance from head to nerve ring (Table I; Fig. 1A and E). Main part of body curled (Fig. 4).

Cuticle: thin in anterior part with external delicate striations, not visible at low magnification (Fig. 1A). Cuticle progressively thickened and complex in structure. Cuticle 28-32 $\mu \mathrm{m}$ thick in coiled main part of body, composed of four or five layers (Figs 1F, I, and 7).
External layer with transverse salient ridges, 25-45 $\mu \mathrm{m}$ apart, straight, interrupted, not branched on lateral fields (Figs 1G, H, and 14, *); incomplete ridges very rare (Fig. $1 G, *$ ). Median layer of cuticle thick, divided with internal transverse striae; a constant two striae between adjoining ridges (Figs $1 \mathrm{H}, \mathrm{I}, 8$, and 9, arrows). Layers appeared dotted or not in transverse section, depending on whether the cuticlar fibers were transverse (Fig. 1F) or longitudinal (Fig. 1I).

Tranverse section of body round; cuticle not thickened laterally (Figs $1 \mathrm{~F}$ and 7). Body musculature welldeveloped, lateral chords narrow (Fig. 1H, dotted area). Ridges less distant in posterior end, internal striae not visible (Fig. 1J). Tail cuticle with transverse external 


\begin{tabular}{|c|c|c|c|c|c|c|c|c|c|c|c|c|}
\hline \multirow[b]{2}{*}{$\begin{array}{c}\text { Sika ID } \\
\text { no. }\end{array}$} & \multicolumn{8}{|c|}{ O. eberbardi n. sp. } & \multicolumn{4}{|c|}{ Co-existence with other filarioids } \\
\hline & Face & Ears & Neck & $\begin{array}{c}\text { Thoracic } \\
\text { limbs }\end{array}$ & Midback & Abdomen & $\begin{array}{l}\text { Pelvic } \\
\text { limbs }\end{array}$ & Tail & $\begin{array}{c}C . \\
\text { crassa }\end{array}$ & $\begin{array}{c}\text { C. } \\
\text { longa }\end{array}$ & $\begin{array}{c}\text { M. (C.) } \\
\text { perforata }\end{array}$ & $\begin{array}{c}\text { O. } \\
\text { skrjabini }\end{array}$ \\
\hline S11 & + & ++ & + & - & - & ND & - & - & + & + & + & - \\
\hline S14 & - & + & - & ND & - & - & - & - & - & + & + & - \\
\hline S15 & + & + & + & - & - & - & - & - & + & + & ++ & ++ \\
\hline S18 & + & ++ & + & + & - & - & - & - & - & - & - & + \\
\hline S19 & + & + & - & - & - & - & - & - & - & + & +++ & +++ \\
\hline S20 & ND & ND & + & - & - & - & - & - & + & + & +++ & +++ \\
\hline S21 & ND & + & + & - & - & - & - & - & - & - & - & - \\
\hline S23 & - & + & + & - & - & + & - & - & + & + & + & + \\
\hline S24 & - & - & - & + & - & - & - & - & + & + & - & - \\
\hline S25 & + & + & + & - & - & - & - & - & + & + & + & + \\
\hline S28 & ND & +++ & ND & - & - & - & - & - & - & + & - & - \\
\hline $\mathrm{S} 30$ & ND & + & ND & + & - & - & - & - & - & + & - & + \\
\hline S31 & ND & + & ND & - & - & - & - & - & - & - & + & +++ \\
\hline S32 & ND & ++ & ND & - & - & - & - & - & - & + & - & - \\
\hline S33 & ND & +++ & ND & - & - & - & - & - & - & + & - & - \\
\hline S34 & ND & + & ND & - & - & - & - & - & - & - & + & +++ \\
\hline Total & 5 & 14 & 7 & 3 & 0 & 1 & 0 & 0 & 6 & 12 & 9 & 9 \\
\hline $\begin{array}{l}\text { Detection } \\
\text { rate }\end{array}$ & $(5 / 8)$ & $(14 / 15)$ & $(7 / 10)$ & $(3 / 15)$ & 0 & $(1 / 15)$ & 0 & 0 & $(6 / 16)$ & $(12 / 16)$ & $(9 / 16)$ & $(9 / 16)$ \\
\hline
\end{tabular}

"Number of microfilariae: (-) not found; (+) 1-9; (++) 10-19; (+++) 20 or more. ND: not done."

Table III. - Distribution of microfilariae of Onchocerca eberhardi n. sp. in skin snips of sika deer with such microfilariae in Oita, Kyushu, and their co-existence with other kinds of microfilariae of filarioids.

striations and no ridges; sometimes, a few tiny bosses on cuticle (Fig. 1K, L). Posterior end twisted (Fig. 1J). Tail straight; posterior end smooth but with internal terminal point and two subterminal elongated phasmids (Fig. $1 \mathrm{~K}, \mathrm{~L}$ ).

- Microfilaria ( $n=20)$ : microfilariae from ovejector and skin of sika deer unsheathed; body dorsoventally flattened (median view, $4-5 \mu \mathrm{m}$ wide; lateral view, $3.75 \mu \mathrm{m}$ wide; non-fixed microfilariae as indicated in Table I), body widening slightly at anterior extremity; tiny cephalic hook present; tail extremity attenuated to smooth point (Figs $1 \mathrm{M}$ and 11). Uterine microfilariae stained with Giemsa's solution $(n=10)$ : body length 210-238 (mean, 223) $\mu \mathrm{m}$ and width 4-5 (4) $\mu \mathrm{m}$; nerve ring 55-63 (58) $\mu \mathrm{m}$ from anterior end: $26 \%$ of body length; anal pore 192-213 (199) $\mu \mathrm{m}$ from anterior end: $89 \%$ of body length (Fig. 12).

- Male ( $\mathrm{n}=10)$ : slight cervical swelling at anterior end (Fig. 2A). Striations on cuticle of main part of body interrupted in lateral fields (Figs 2D and 15, *). Exceptionally, three body swellings present (two specimens: 4,8 , and $14 \mathrm{~mm}$ from the anterior end in a male worm, $\mathrm{S} 47-5,19 \mathrm{~mm}$ long; 5, 12, and $19 \mathrm{~mm}$ from the anterior end in another male worm, S47-6, $22 \mathrm{~mm}$ long). Area rugosa in posterior end absent. Right spicule with knobbed posterior end; sub-terminal dorsal heel (Fig. 2F). Left spicule with handle and lamina; attenuated long distal extremity (Fig. 2G). Nine pairs of caudal papillae arranged in two groups: $i$ ) one unpaired precloacal papilla near the cloacal aperture; four paracloacal sublateral pairs (probably pairs 2, 3, 4, and 6) and one subventral postcloacal pair (pair 5); ii) four pairs aligned in posterior third of tail: small pair 7 , large pair 8 , pointed pair 9 with phasmids at base, and terminal pair 10. In several specimens, the cloacal group contained only three pairs, whereas the posterior group remained constant (Table II; Fig. 2I, J).

\section{PREVALENCE AND DISTRIBUTION OF ADULT WORMS AND MICROFILARIAE OF O. EBERHARDI N. SP. IN SIKA DEER AND THEIR CO-EXISTENCE WITH OTHER FILARIOIDS}

Adult worms were found in the limbs of sika deer from Oita $(17 / 21$ or $81 \%)$ by dissection or treatment by collagenase (six of 17 deer with such parasites were treated by collagenase). In one (S59) of two deer treated by collagenase, 25 anterior parts of adult females (with one complete female) and 16 complete males of O. eberhardi $\mathrm{n}$. sp. were found in a carpal ligament; none were found in the tarsal ligament treated by collagenase or anywhere on the entire skin inspected by a stereomicroscope. In another sika (S64), 10 anterior parts of females and six complete males were found in the carpal ligament examined and only one female fragment was taken from the tarsal ligament. Thus, rather than the tarsal ligament, almost all the adult parasites had wound themselves within the carpal ligament (Table II). Inflammation with congestion was found in the carpal ligament parasitized by many worms (Figs 5 , 6 and 10).

Microfilariae of $O$. eberhardi n. sp. were found in skin snips of 44 of $54(81 \%)$ sika deer from Oita. Skin 


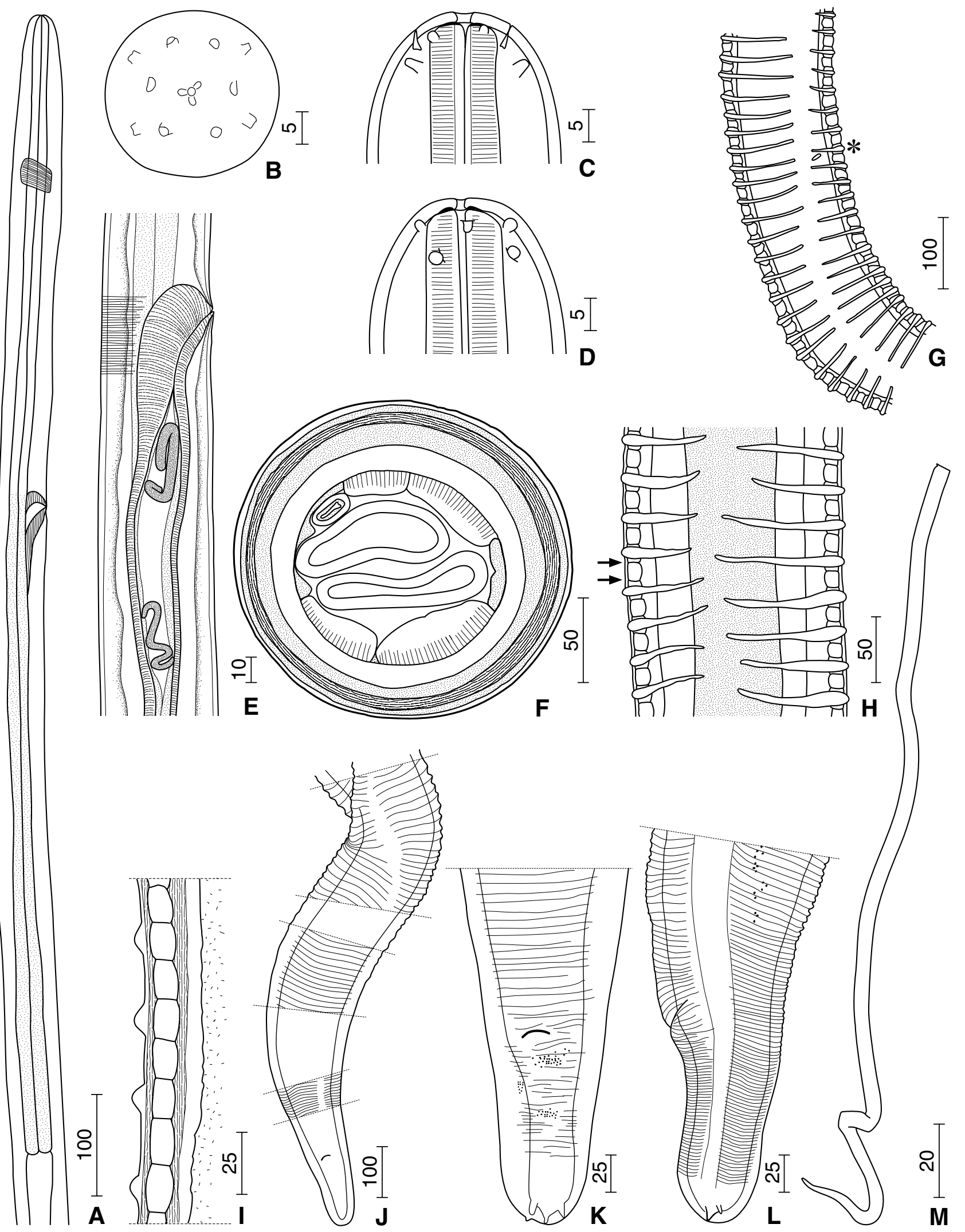

Fig. 1. - Onchocerca eberhardi n. sp., females. A. Anterior end, right lateral view. B. Head, apical view. C. Head, median view. D. Head, lateral view. E. Region of vagina, right lateral view. F. Cross-section of body in the coiled main part. G. Cuticular ornamentation of body, sublateral view. Incomplete ridge (*). H. Ridges and striae (arrows), lateral view (dotted area: lateral chord). I. Detail of cuticle, longitudinal view. J. Posterior region, twisted. K. Tail, ventral view. L. Tail, lateral view. M. Microfilaria from ovejector. Bars, micrometers. 
microfilariae were in the ears (41/50 or $82 \%)$, neck, and face; a few were found in the skin of thoracic limbs $(10 / 52$ or $19 \%)$, back $(6 / 52$ or $12 \%)$, or abdomen $(3 / 51$ or $6 \%)$; no skin microfilariae were in pelvic limbs (51 deer examined) or tail (46 deer examined). Distribution of microfilariae from 16 sika deer is listed in Table III. In addition, skin microfilariae of O. eberhardi n. sp. were found in four of the nine sika deer from Kumamoto Prefecture, Kyushu. No microfilariae were found in the blood films and no lesions were found in the eyeballs of the six sika deer examined.

Adult worms and microfilariae of O. eberhardi n. sp. were found co-occurring with one, two, or three species of C. crassa, C. longa, M. (C.) perforata, and O. skrjabini in sika deer (Table III). Four sika deer (S15, 20, 23, and 25) were infected with all five filarial species including $O$. eberhardi n. sp. Parasitic locations of the adult worms of these filarioids were different: C. crassa

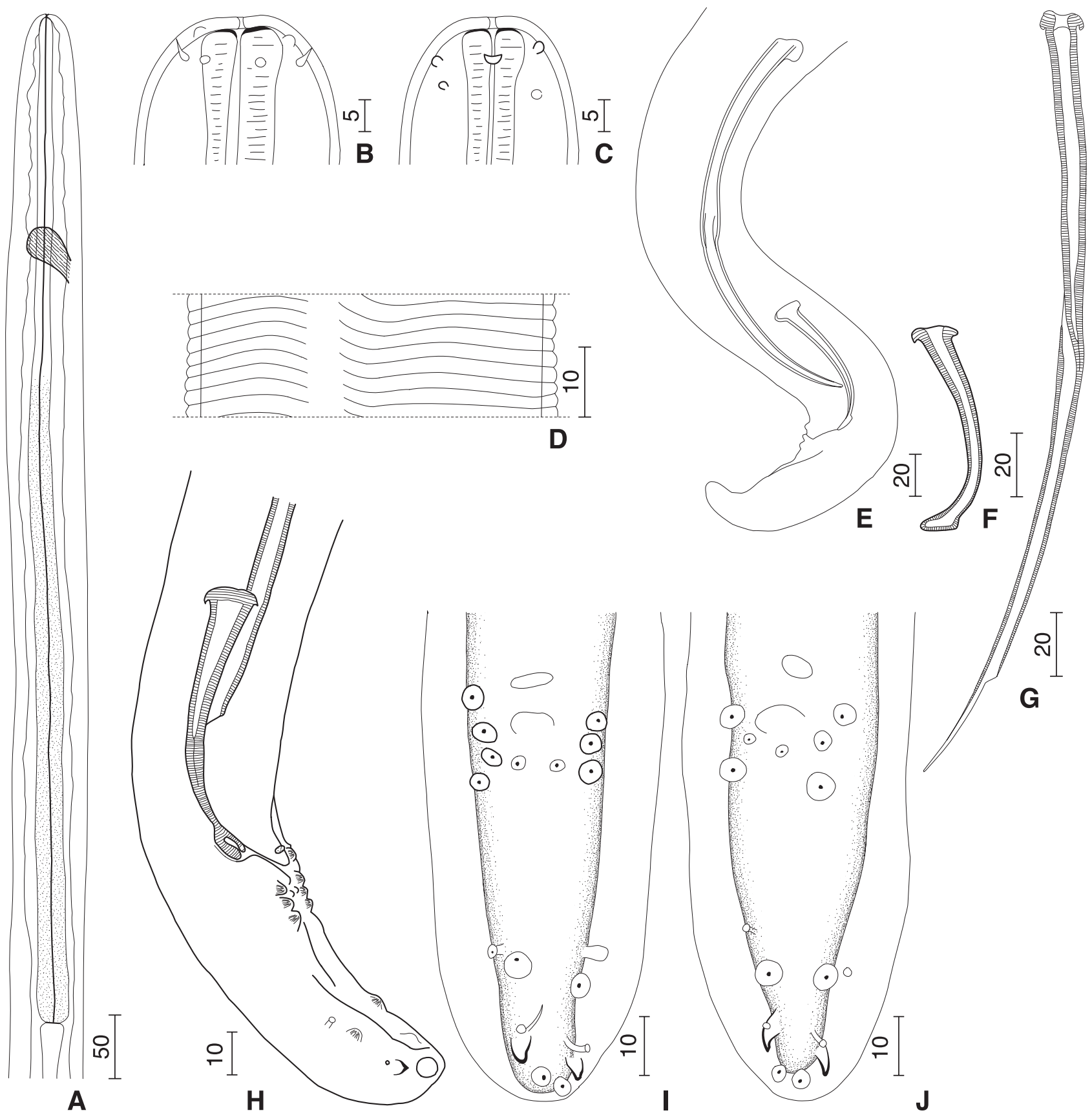

Fig. 2. - Onchocerca eberhardi n. sp., males. A. Anterior end, right lateral view. B. Head, median view. C. Head, lateral view. D. Cuticular ornamentation at midbody, lateral view. E. Posterior region, lateral view. F. Right spicule, lateral view. G. Left spicule, lateral view. H. Tail, right lateral view. I. Tail, ventral view. J. Tail of another male, ventral view. Bars, micrometers. 

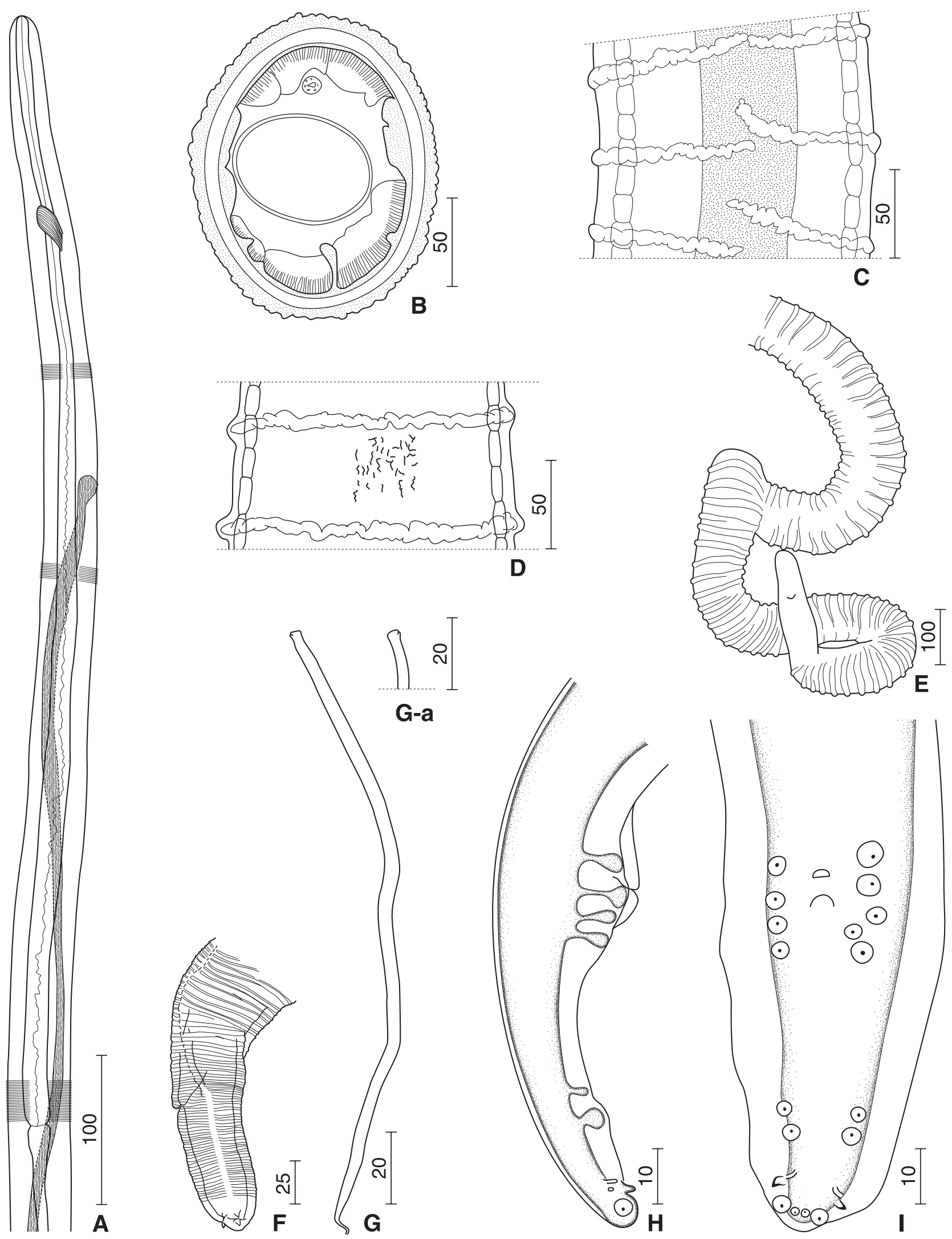

Fig. 3. - Onchocerca stilesi Eberhard, 1979. A-F. Female holotype. A. Anterior end, right lateral view. B. Cross-section at midbody. C. Cuticular ornamentation at midbody, lateral view (dotted area: lateral chord). D. Cuticular ornamentation, median view. E. Posterior region, twisted. F. Tail, left lateral view. G. Microfilaria in ovejector, median view. G-a. Anterior end of microfilaria, median view. H and I. Male paratype. H. Tail, right lateral view. I. Tail, ventral view. Bars, micrometers. 

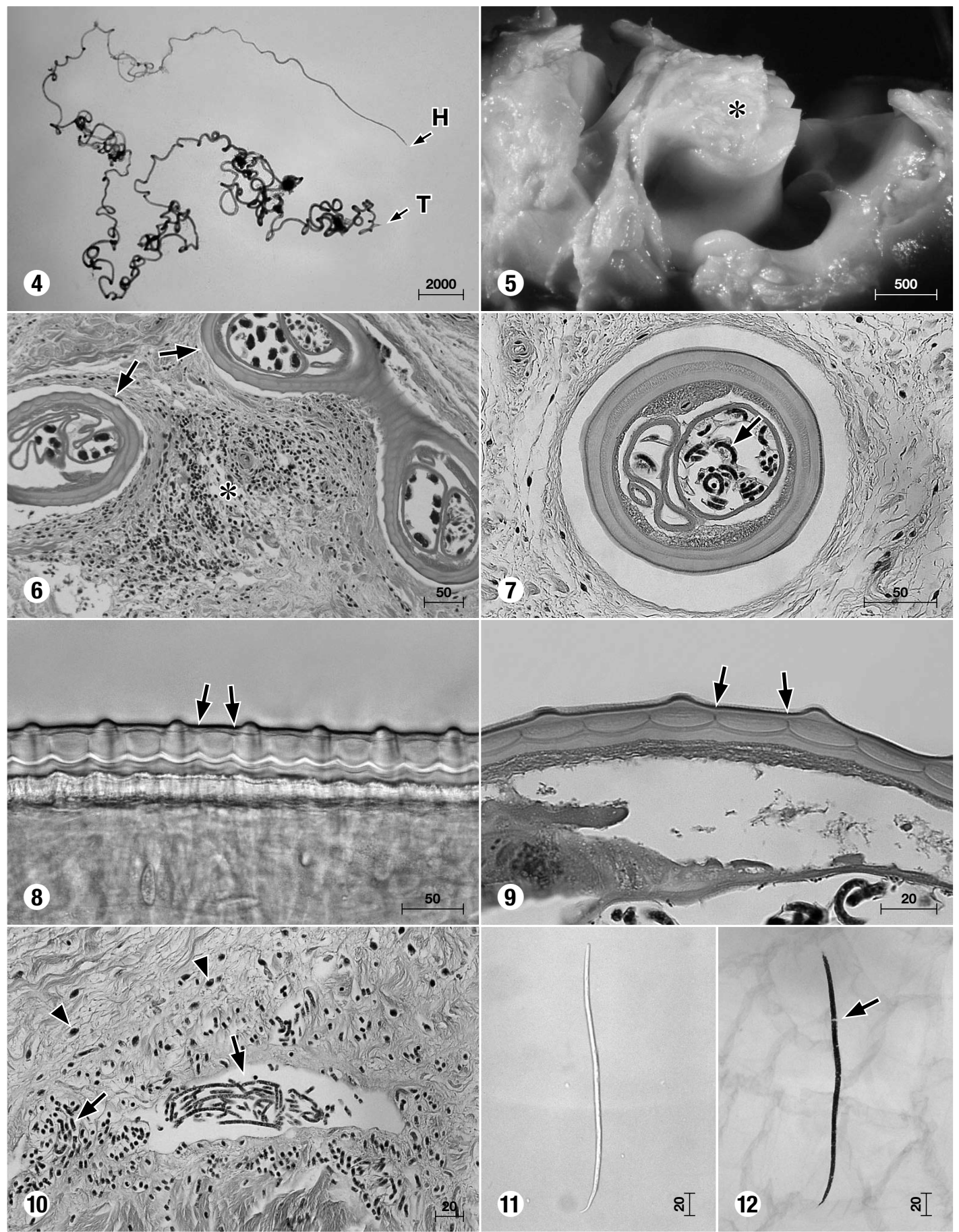

Fig. 4. - A complete female of Onchocerca eberbardi n. sp. Head (H) and tail (T). Bar, micrometers.

Fig. 5. - Carpal ligament $\left(^{*}\right)$ of sika deer, parasitized by adult worms of Onchocerca eberhardi n. sp. after collagenase treatment. Bar, micrometers.

Fig. 6. - Parasitic lesion of the carpal ligament. Inflammation seen near females (arrows) of Onchocerca eberhardi n. sp. Inflammatory cells (*). Bar, micrometers.

Fig. 7. - Transverse section of a female Onchocerca eberhardi n. sp. in the carpal ligament. Microfilaria (arrow). Bar, micrometers.

Fig. 8. - Cuticle of a female Onchocerca eberhardi n. sp. seen by differential interference contrast microscopy. Striae (arrows). Bar, micrometers.

Fig. 9. - Longitudinal histologic section of the cuticle of a female Onchocerca eberhardi n. sp. Striae (arrows). Bar, micrometers.

Fig. 10. - Microfilariae (arrows) in the tissue of the carpal ligament parasitized by females of Onchocerca eberhardi n. sp. Large inflammatory cells (arrowheads). Bar, micrometers.

Fig. 11. - Microfilaria taken from ovejector of a female Onchocerca eberhardi n. sp. Bar, micrometers.

Fig. 12. - Microfilaria taken from ovejector of a female Onchocerca eberhardi n. sp., stained with Giemsa's solution. Nerve ring (arrow). Bar, micrometers. 
in the dermis of the anterior back, C. longa in the subcutaneous connective tissues of the limbs, and $M$. (C.) perforata in the dermis of the posterior back.

Microfilariae of O. skrjabini were found in the skin of sika deer (8/22 or $36 \%)$, mainly of the ears and neck. The adult worms of the species were found in the subcutaneous connective tissues around the carpal and tarsal regions of sika deer. One complete female worm (S20-1; $60.5 \mathrm{~cm}$ long and $300 \mu \mathrm{m}$ wide) was found in a sika deer (S20) on Mt. Sobo, Taketa City, Oita Prefecture, Kyushu. The findings constitute a new host record for O. skrjabini in the sika deer.

\section{TAXONOMIC SUMMARY}

Type host: Cervus nippon Temminck (sika deer), Cervidae.
Location in host: adult worms in the carpal ligament. Microfilariae in the skin, mainly of the ears.

Type locality: Mt. Sobo, Kiyokawa-cho, Oita Prefecture, Kyushu, Japan.

Collection dates: type specimens on 15 February 2004; other specimens between 26 September 1998 and 13 February 2006.

Specimens deposited: female holotype (S59-C36), collection number $140 \mathrm{JW}$, the Museum National d'Histoire Naturelle (MNHN), Paris; male allotype (S59-C38), 227 JW, MNHN. Paratype: three males (S59-C28, S59-C29, and S59-C37), $228 \mathrm{JW}, 229 \mathrm{JW}$, and $230 \mathrm{JW}, \mathrm{MNHN}$, respectively; three males (S59-C1, S59-C3, and S59-9) in the Department of Medical Zoology, Osaka City University Medical School (OCUMS). Other specimens: the anterior part of one female (S34-21) and one male (S34-
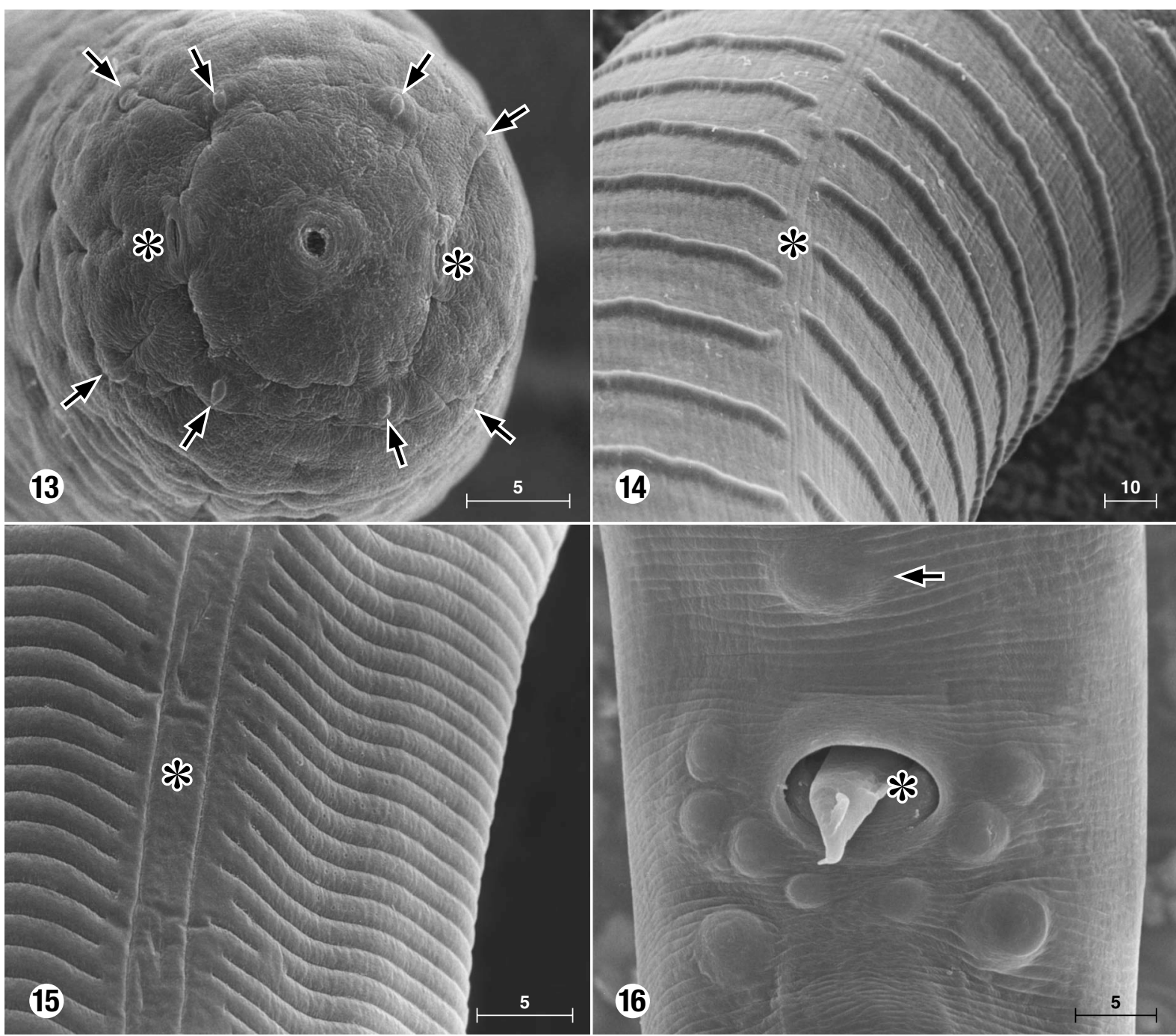

Fig. 13. - SEM of anterior end of a female Onchocerca eberhardi n. sp., amphids (*) and papillae (arrows). Bar, micrometers. Fig. 14. - SEM of transverse ridges on the midbody of a female Onchocerca eberbardi $\mathrm{n}$. sp. Lateral field (*). Bar, micrometers Fig. 15. - SEM of midbody of a male Onchocerca eberhardi n. sp. Lateral field (*). Bar, micrometers.

Fig. 16. - SEM of caudal papillae near cloaca of a male Onchocerca eberhardi n. sp. Precloacal papilla (arrow) and cloaca (*). Bar, micrometers. 
10), $139 \mathrm{JW}, \mathrm{MNHN}$; two anterior parts of females with microfilariae (S29-8 and S59-C44), one posterior part of young female (S29-32), and two males (S29-26 and S29-30), 127 JW, MNHN; 130 fragment females, 37 complete males, and 20 fragment males in OCUMS.

Etymology: we named this species O. eberhardi n. sp. in honor of Dr. Mark L. Eberhard, U.S.A., for his contribution to the knowledge of filarioids.

\section{ONCHOCERCA STILESI EBERHARD, 1979 (Tables I, II; Fig. 3)}

- Female (holotype): Very thin anterior end $5 \mathrm{~mm}$ long (Table I; Fig. 3A). Esophagus slender without distinct glandular part. Vulva in anterior half of esophagus; its distance to head equal to twice distance from nerve ring to head. Cuticle thin in anterior part of body, with conspicuous transverse external striae. Body musculature well developed, lateral chords narrow (Fig. 3B). Body round in transverse section, cuticle not thickened laterally. In main part of body (Fig. 3C, D), two cuticle layers, 25-30 $\mu \mathrm{m}$ thick: external layer with transverse ridges, undulated, jointed or overlapped on lateral fields, surface cuticle wrinkled; internal layer divided with transverse striae; a constant three striae between adjoining ridges. Posterior end coiled (Fig. 3E). Ridges present in preanal region but closer, 5-7 $\mu \mathrm{m}$ apart; tail with external striations, but no ridges (Fig. 3F). Tail straight; extremity round with lateral point near each phasmid.

- Microfilariae (from ovejector of female holotype): Body 177-190 um long, 4-5 um wide; slight constriction behind head; tiny cephalic hook; tail extremity attenuated (Fig. 3G, G-a).

- Male (paratype): Esophagus with glandular part. Caudal papillae in two groups: $i$ ) paracloacal group with one unpaired papilla and four to five aligned sublateral pairs (two anterior and three posterior to cloacal aperture); $i$ ) four pairs in posterior third of tail with pair 7 small, pair 8 large, pair 9 pointed with phasmid at base, and pair 10 terminal. Tail tip with two small ventral transparent papilla-like formations (Fig. 3I). Right spicule with knobbed extremity and subterminal dorsal heel; left spicule with attenuated long distal extremity, as previously described (Eberhard, 1979).

\section{TAXONOMIC DISCUSSION}

$\mathrm{F}$ Tor the diagnosis of the material from the sika deer we used the morphologic characteristics selected in the dichotomous key proposed by Bain (1981) for 24 species of Onchocerca, after revision and description of many species were made by several authors (Bain, 1975, 1981; Bain \& Schulz-Key, 1974, 1976; Bain et al., 1978a, b, 1980; Bain \& Beveridge, 1979a, b; Eberhard, 1979; Denké \& Bain, 1981). At that time, 26 species of Onchocerca were known, but two of these species were not included in the key because they were considered insufficiently defined: O. stilesi from cattle, for which an important distinctive characteristic, the microfilaria, was not described (Eberhard, 1979) and O. lupi Rodonaja, 1967 from a wolf (Rodonaja, 1967) which at the time was thought to be either a transfuge parasite from an ungulate, or an error of collection labelling. In the present study, the short microfilaria of $O$. stiles $i$ confirmed the validity of this species (Table I). The identity of $O$. lupi has been established by morphologic analysis of new materials collected from dogs in Eastern Europe (Demiaszkiewicz \& Matsaberidze, 1991; Demiaszkiewicz et al., 1991; Egyed et al., 2001; Sréter et al., 2002) and by molecular analysis of the filarial worms and their Wolbachia symbionts (Egyed et al., $2002 \mathrm{a}, \mathrm{b})$. In addition to these two species, the present taxonomic discussion includes the five species described after 1981: O. alcis Bain \& Rehbinder, 1986 from cervids (Bain \& Rehbinder, 1986), two species O. denkei Bain, Vassiliades \& Delbove, 1982 and O. suzukii from bovids (Bain et al., 1982; Yagi et al., 1994), and two species O. ramachandrini Bain, Wahl \& Renz, 1993 and O. dewittei japonica from suids (Bain et al., 1993; Uni et al., 2001), totaling 31 Onchocerca species (with one subspecies).

Onchocerca eberhardi n sp. stands in contrast to those six species with an esophagus longer than 2,000 $\mu \mathrm{m}$ and with thicker posterior glandular part, in female and male, and vulva not far from head (twice the distance from the head to nerve ring). These species are O. raillieti Bain, Muller, Khamis, Guilhon \& Schillhorn Van Veen, 1976, O. reticulata Diesing, 1841, and O. cervicalis Railliet \& Henry, 1910 from equids; O. flexuosa (Wedl, 1856) from cervids; O. armillata Railliet \& Henry, 1909 from bovids. Onchocerca fasciata Railliet \& Henry, 1910 from camelids, [which in the key (Bain, 1981) is shown as apart from these species because the vulva is slightly less anterior], has similar esophageal morphology. In addition, females of these species have a thick anterior end (about $200 \mu \mathrm{m}$ wide at the posterior end of the esophagus).

Among the remaining 25 species with an esophagus shorter than 2,000 $\mu \mathrm{m}$ in both sexes, O. eberbardi n. sp. stands in contrast to those of the nodular lineage with muscles atrophied and hypodermis hypertrophied in the female (Bain \& Beveridge, 1979a; Bain, 2002). The seven species are O. volvulus (Leuckart, 1893) from humans; O. gibsoni, O. cebei Galliard, 1937, O. ochengi Bwangamoi, 1969, O. dukei Bain, Bussieras \& Amégée, 1974, O. schulzkeyi Denké \& Bain, 1981, and O. hamoni Denké \& Bain, 1981, all from bovids.

Among the following six species, some do not have a complex female cuticle with ridges and striae, contrary 
to O. eberhardi n. sp. $i$ ) Transverse ridges are absent in O. suzukii from bovids and O. bohmi (Supperer, 1953) from equids; in addition, the former has a distinctly divided esophagus, 1,660-1,910 $\mu \mathrm{m}$ long in females, and large spicules (Yagi et al., 1994); the latter has a microfilaria with a long caudal filament (Supperer, 1953). In O. cervipedis Wehr \& Dickmans, 1935 from cervids, the ridges are flat and not distant, so that they resemble the primitive common external striation of nematodes; the anterior end of the female is thick (220-270 $\mu \mathrm{m}$ wide at the posterior end of the esophagus). ii) The internal striae are absent in O. dewittei dewittei Bain, Ramachandran, Petter \& Mak, 1977, $O$. ramachandrini, and $O$. dewittei japonica from suids (Takaoka et al., 2004); in addition, body swellings are present in females of these three species (Uni et al., 2001). The anterior region of the female of O. ramachandrini is not very attenuated $(\geq 90 \mu \mathrm{m}$ wide at posterior end of esophagus).

Five species have transverse ridges and striae like O. eberhardi $\mathrm{n}$. sp. In four of these species the vulva is more posterior, near the posterior end of the esophagus (three to six times the distance from nerve ring to head) and the internal cuticle presents three to four striae between adjacent ridges. These species are parasitic in cervids: O. skrjabini, O. garmsi Bain \& Schulz-Key, 1976, O. jakutensis (Gubanov, 1964) (= O. tubingensis Bain \& Schulzkey, 1974; Sonin, 1975), and O. alcis. In addition, the microfilaria is large in O. skrjabini (400-410 $\mu \mathrm{m}$ long, 11$12 \mu \mathrm{m}$ wide; Bain \& Schulz-Key, 1974) and O. garmsi (287-330 $\mu \mathrm{m}$ long, 7.4-8.4 $\mu \mathrm{m}$ wide; Bain \& Schulz-Key, 1976). The esophagus is short, $\leq 850 \mu \mathrm{m}$, with a thick glandular part in O. jakutensis and O. alcis (Bain \& Schulz-Key, 1976; Bain \& Rehbinder, 1986). Onchocerca lupi in carnivores has two striae between adjoining ridges; at a length of $80-105 \mu \mathrm{m}$, its microfilaria is short and 5-7 $\mu \mathrm{m}$ relatively thick (Demiaszkiewicz \& Matsaberidze, 1991; Egyed et al., 2001; Sréter et al., 2002).

Four species (O. beaveri Bain, Chabaud \& Landau, 1978a, O. lerouxi Bain, Chabaud \& Landau, 1978a, and O. sonini Bain, Chabaud \& Landau, 1978a from bovids in a Central African forest and $O$. denkei from a West African bovid) are similar to O. eberhardi n. sp. in the position of the vulva (two to three times the distance from the head to nerve ring). However, the esophagus in females has a distinct glandular part in O. beaveri, O. lerouxi, and O. sonini; in addition, the esophagus in all three of these species is longer $(1,310-1,960 \mu \mathrm{m}$ in females and 980-1,460 $\mu \mathrm{m}$ in males; Bain et al., 1978a) than in O. eberhardi n. sp. Onchocerca denkei has a short esophagus, 1,020 $\mu \mathrm{m}$ long, in the female (Bain et al., 1982), close to the maximum in O. eberhardi n. sp. However, O. denkei has reduced muscles, a thick hypodermis, four striae between ridges, and a large body diameter at the posterior end of the esophagus, which is twice as thick as in our specimens.
The last three species (O. gutturosa, O. lienalis, and $O$. stilesi) resemble $O$. eberhardi n. sp., because the females have a long thin anterior body $(\leq 80 \mu \mathrm{m}$ wide at the posterior end of esophagus), and an esophagus about $1,000 \mu \mathrm{m}$ long, with a slightly differentiated glandular part or none at all (Table I). The species are all parasitic in bovids (cattle). Onchocerca gutturosa has four to seven striae per inter-ridge, sinuous ridges branched in lateral fields, asymmetric female body, pronounced reduction of caudal papillae, and longer left spicule in the male (Bain, 1975; Bain et al., 1978b). Onchocerca lienalis and O. stilesi are 50-55 $\mu \mathrm{m}$ wide in body width at the posterior end of esophagus like the majority of our specimens (Table I). Onchocerca lienalis has two striae per inter-ridge, like our specimens, but ridges are present only in the posterior end, and the female has longitudinal wrinkles on the body (Bain et al., 1978b). Onchocerca stilesi has three striae per inter-ridge; the ridges are sinuous and joined on the lateral field or overlapped (Fig. 3C); the microfilaria is shorter than that of O. eberhardi n. sp. (177$190 \mu \mathrm{m}$ versus 200-258 $\mu \mathrm{m}$ ). The measurements of O. eberhardi n. sp. seem to be different from those of O. stilesi: the more posterior position of the nerve ring, longer esophagus, and longer tail in both sexes and longer left spicule in male worms. Also, Onchocerca eberbardi n. sp. is distinct from these three bovid-host species in its location, the carpal ligament (Tables I, II).

\section{CONCLUSION}

reviously it was emphasized that the species of Onchocerca from cervids were polyphyletic with two main lineages identified: one of primitive species, O. flexuosa and O. cervipedis; the other of derived species, O. skrjabini, O. jakutensis, O. garmsi, and O. alcis (Bain, 1981; Yagi et al. 1994). A bovid parasite, O. suzukii from the Japanese serow, was found to resemble the primitive cervid parasite, O. flexuosa, suggesting a common ancestor (Yagi et al., 1994).

The new species, O. eberhardi, appears to be an evolved species with the complex cuticle, reduction of glandular esophagus, and transformation of papillae pair 9 into a cuticular point. But this species differs from the other evolved parasites of cervids in a rather important characteristic, the more anterior position of the vulva. This difference brings $O$. eberhardi n. sp. closer to a group of species parasitic in bovids: O. stilesi, O. lienalis, and O. gutturosa.

The lineages of Onchocerca in cervids are probably the results of successive waves of diversification, which may have occurred simultaneously in bovids. However, these relationships were restricted to the areas where the cervids lived, almost all of which lie in the Holarctic 
region. In tropical areas, other distinct lineages of Onchocerca may have expanded in bovids.

\section{ACKNOWLEDGEMENTS}

W

e thank Drs K. Hayashi, T. Hoshina, and T. Onoe, Osaka City University Medical School, for examining the sika deer for parasites and Drs Y. Gouto and A. Obana, Department of Ophthalmology, for inspecting the eyes of the sika deer. Thanks also to Mr T. Kenkou of the Central Laboratory of Osaka City University Medical School for the histologic preparation and $\mathrm{Mr} \mathrm{H}$. Nakagawa of the same laboratory for SEM examination of the parasites. We thank Mr J.L. Yohay for reading the manuscript. We thank Drs E.P. Holberg and P. Pilitt, U.S. National Parasite Collection, Agricultural Service, for lending the Onchocerca stilesi specimens. This study was partly supported by grants for the overseas research program of Osaka City University and by the Muséum National d'Histoire Naturelle, Paris, where S. Uni, as a visiting researcher, collaborated with $\mathrm{O}$. Bain between July and September, 2005.

\section{REFERENCES}

Bain O. Redescription de cinq espèces d'onchocerques. Annales de Parasitologie Humaine et Comparée, 1975, 50, 763-788.

BAIN O. Le genre Onchocerca : hypothèses sur son évolution et clé dichotomique des espèces. Annales de Parasitologie Humaine et Comparée, 1981, 56, 503-526.

BAIN O. Evolutionary relationships among filarial nematodes, in: World Class Parasites, 5, The Filaria. Klei T.R. \& Rajan T.V. (eds), Kluwer Academic Publishers, Boston, 2002, 2129.

BaIn O. \& Beveridge I. Redescription d'Onchocerca gibsoni Cleland \& Johnston, 1910. Annales de Parasitologie Humaine et Comparée, 1979a, 54, 69-80.

Bain O. \& Beveridge I. Redescription du mâle d'Onchocerca lienalis (Filarioidea, Nematoda). Annales de Parasitologie Humaine et Comparée, 1979b, 54, 117-118.

Bain O., Bussieras J. \& AmégéE E. Dualité d'Onchocerca volvulus de l'homme et d'O. sp. Cameron, 1928, du bétail. Nouvelles espèces d'onchocerques bovines au Togo. Comptes rendus hebdomadaires des Séances de l'Academie des Sciences. Série D : Sciences naturelles, 1974, 278, 369372.

Bain O., Chabaud A.G. \& Landau I. Trois nouvelles onchocerques chez des Céphalophes du Gabon. Annales de Parasitologie Humaine et Comparée, 1978a, 53, 403-419.

Bain O., Chabaud A.G., Wanantasamruad P. \& Nabhitabhata J. Onchocerca sweetae chez le buffle en Thailande. Annales de Parasitologie Humaine et Comparée, 1980, 55, 253-257.

Bain O., Muller R.L., Khamis Y., Guilhon, J. \& Schillhorn Van VEEN T. Onchocerca raillieti n. sp. (Filarioidea) chez l'âne domestique en Afrique. Journal of Helminthology, 1976, 50, 287-293.

Bain O., PettT G. \& Poulain B. Validité des deux espèces Onchocerca lienalis et O. gutturosa, chez les bovins. Annales de Parasitologie Humaine et Comparée, 1978b, 53, 421-430.

Bain O., Ramachandran C.P., Petter F. \& Mak J.W. Description d'Onchocerca dewittei n. sp. (Filarioidea) chez Sus scrofa en Malaisie. Annales de Parasitologie Humaine et Comparée, 1977, 52, 471-479.

BAIN O. \& REHBInder C. Nouvelle onchocerque, Onchocerca alcis n. sp. parasite de l'élan, Alces alces, en Suède. Annales de Parasitologie Humaine et Comparée, 1986, 61, 447-455.

BAIN O. \& Schulz-Key H. Les onchocerques du cerf européen : redescription d'O. flexuosa (Wedl, 1856) et description d'O. tubingensis n. sp. et O. tarsicola n. sp. Tropenmedizin und Parasitologie, 1974, 25, 437-449.

BAIN O. \& Schulz-Key H. Une quatrième espèce d'onchocerque, O. garmsi n. sp., chez le cerf européen. Tropenmedizin und Parasitologie, 1976, 27, 474-478.

Bain O., Vassiliades G. \& Delbove P. Une nouvelle onchocerque, parasite de bovin domestique, au Sénégal. Annales de Parasitologie Humaine et Comparée, 1982, 57, 587-591.

BAIN O., WAHL G. \& RENZ A. Onchocerca ramachandrini n. sp. from the warthog in Cameroon. Annales de Parasitologie Humaine et Comparée, 1993, 68, 139-143.

BARUš V. \& KoubeK P. Evidence on the occurrence of Onchocerca skrjabini (Nematoda: Onchocercidae) in the Czech Republic. Helminthologia, 1993, 30, 105-108.

Beaver P.C., Hira P.R. \& Patel B.G. Onchocerciasis in Zambia: report of $O$. volvulus in a child and its differentiation from O. dukei in cattle. Transactions of the Royal Society of Tropical Medicine and Hygiene, 1983, 77, 162-166.

Beaver P.C., Horner G.S. \& Bilos J.Z. Zoonotic onchocercosis in a resident of Illinois and observations on the identification of Onchocerca species. The American Journal of Tropical Medicine and Hygiene, 1974, 23, 595-607.

BwANGAMOI O. Onchocerca ochengi new species, an intradermal parasite of cattle in East Africa. Bulletin of Epizootic Diseases of Africa, 1969, 17, 321-335.

Bylund G., Fagerholm H.P., Krogell C. \& Nikander S. Studies on Onchocerca tarsicola Bain and Schulz-Key, 1974 in reindeer (Rangifer tarandus) in northern Finland. Journal of Helminthology, 1981, 55, 13-20.

Chabaud A.G. \& Petter A.J. Remarques sur l'évolution des papilles cloacales ches les nématodes phasmidiens parasites de vertébrés. Parassitologia, 1961, 3, 51-70.

Demiaszkiewicz A.W. \& Matsaberidze G.V. New details of morphology of Onchocerca lupi (Nematoda, Filarioidea). Wiadomości Parazytologiczne, 1991, 37, 255-259 (in Polish).

Demiaszkiewicz A.W., Matsaberidze G.V. \& Kvavadze E.Sh. The female of Onchocerca lupi Rodonaja, 1967 under a scanning electron microscope. Acta Parasitologica Polonica, 1991, 36, 183-186.

Denké A.M. \& Bain O. Deux nouvelles onchocerques nodulaires chez des bovidés sauvages, en Haute-Volta. Annales de Parasitologie Humaine et Comparée, 1981, 56, 339-347.

EBERHARD M.L. Studies on the Onchocerca (Nematoda: Filaroidea) found in cattle in the United States. I. Systematics 
of $O$. gutturosa and O. lienalis with a description of $O$. stilesi sp. n. The Journal of Parasitology, 1979, 65, 379-388.

Egyed Z., Sréter T., Széll Z., Beszteri B., Oravecz O., MáriaLIGETI K. \& VARGA I. Morphologic and genetic characterization of Onchocerca lupi infecting dogs. Veterinary Parasitology, 2001, 102, 309-319.

Egyed Z., Sréter T., Széll Z., Nytrö G., Márialigeti K. \& Varga I. Molecular phylogenetic analysis of Onchocerca lupi and its Wolbachia endosymbiont. Veterinary Parasitology, 2002a, 108, 153-161.

Egyed Z., Sréter T., Széll Z., Nyirö G., Dobos-Kovács M., MÁrialigeti K. \& VARGa I. Electron microscopic and molecular identification of Wolbachia endosymbionts from Onchocerca lupi: Implications for therapy. Veterinary Parasitology, 2002b, 106, 75-82.

Engelkirk P.G., Williams J.F., Schmidt G.M. \& Leid R.W. Zoonotic onchocerciasis. in: Handbook Series in Zoonoses. Section C: Parasitic Zoonoses Vol. II. Schultz M.G. (ed.), CRC Press, Inc., Boca Raton, Florida, 1982, 225-250.

ITAGAKI S. A review on filarial study in Japan. The Science Reports of the Azabu Veterinary College, 1954, 1, 1-10.

OrIHel T.C. \& EBERHARD M.L. Zoonotic filariasis. Clinical Microbiology Reviews, 1998, 11, 366-381.

Railliet A. \& Henry A. Les onchocerques, nématodes parasites du tissu conjonctif. Comptes Rendus des Séances de la Société de Biologie, 1910, 68, 248-251.

Rodonaja T.E. [New species of nematode, Onchocerca lupi n. sp. from Caucasian wolf] Soobshcheniya Akademii Nauk Gruzinskoy S.S.R., 1967, 45, 715-719 (in Russian).

RukHLYADEV D. P. [Helminth fauna of wild ungulates of the Crimea and the Caucasus in ecological and zoogeographical view]. Izdatel'stvo Saratovskogo Universiteta Publishers, Saratov, Russia, 1964, 448, (in Russian).

SchulZ-Key H. Untersuchungen über die Filarien der Cerviden in Süddeutschland. 2. Die Filarien des Rothirsches (Cervus elaphus). Tropenmedizin und Parasitologie, 1975, 26, 348358.

Schulz-Key H. The collagenase technique: How to isolate and examine adult Onchocerca volvulus for the evaluation of drug effects. Tropical Medicine and Parasitology, 1988, 39, 423-440.

SONIN M.D. [Filariata of animals and man and the diseases caused by them. Part 3, Filarioidea: Filariidae and Onchocercinae. Principles of Nematology, 24. Ryzhikov K.M. (ed.)], Nauka, Moscow, 1975, 382-383, (in Russian).

SRÉTER T., Széll Z., Egyed Z. \& VARga I. Ocular onchocercosis in dogs: a review. The Veterinary Record, 2002, 151, 176-180.

Supperer R. Filariosen der Pferde in Österreich. Wiener Tierärztliche Monatsschrift. 1953, 40, 193-220.

Suzuki Y., Sugimura M., Yagi K., Ohbayashi M. \& Shoho C. Onchocerciasis in wild Japanese serows, Capricornis crispus. The Japanese Journal of Veterinary Science, 1982, 44, 823-825.

Suzuki Y., Uni S., Komatsu, T., YAmamoto Y. \& Atoji Y. Olecranon lesions caused by Onchocerca skrjabini in wild Japanese serows (Capricornis crispus). The Journal of Veterinary Medical Science, 1997, 59, 387-390.
TAKAOKA H. Review on zoonotic Onchocerca species and their insect vectors in Japan. Medical Entomology and Zoology, 1999, 50, 1-8.

Takaoka H., Bain O., Uni S., Korenaga M., Kozek W.J., ShiraSAKa C., Aoki C., Otsuka Y., Fukuda M., Eshita Y., DaA T. Zoonotic onchocerciasis caused by a parasite from wild boar in Oita, Japan: A comprehensive analysis of morphological characteristics of the worms for its diagnosis. Parasite, 2004, 11, 285-292.

TAKaOKa H., Bain O., Uni S., Korenaga M., Tada K., IchiKawa H., Otsuka Y. \& Eshita Y. Human infection with Onchocerca dewittei japonica, a parasite from wild boar in Oita, Japan. Parasite, 2001, 8, 261-263.

Takaoka H., Yanagi T., DaA T., AnZai S., Aoki C., Fukuda M., UNI S. \& BAIN O. An Onchocerca species of wild boar found in the subcutaneous nodule of a resident of Oita, Japan. Parasitology International, 2005, 54, 91-93.

Uni S., Bain O., Agatsuma T., Katsumi A., Baba M., Yanai T. \& TAKAOKA H. New filarial nematode from Japanese serows (Naemorhedus crispus: Bovidae) close to parasites from elephants. Parasite, 2006, 13, 193-200.

Uni S., Bain O., TaKaOKa H. Affinities between Cutifilaria (Nematoda: Filarioidea), parasites of deer, and Mansonella as seen in a new onchocercid, $M$. (C.) perforata n. sp., from Japan. Parasite, 2004, 11, 131-140.

Uni S., Bain O., Takaoka H., Miyashita M. \& SuZuki Y. Onchocerca dewittei japonica n. subsp., a common parasite from wild boar in Kyushu Island, Japan. Parasite, 2001, 8, 215222 .

Uni S., Bain O., Takaoka H., Katsumi A., Fujta H. \& Suzuki Y. Diversification of Cercopithifilaria species (Nematoda: Filarioidea) in Japanese wild ruminants with description of two new species. Parasite, 2002, 9, 293-304.

Uni S., Suzuki Y., Katsumi A., Kimata I., Iseki M. \& Bain O. Taxonomy and pathology of filarial parasites from Japanese serows (Capricornis crispus). ICOPA IX, $9^{\text {th }}$ International Congress of Parasitology, Tada I., Kojima S. \& Tsuji M. (eds), Monduzzi Editore, Bologna, Italy, 1998, 681-684.

Wehr E.E. \& Dikmans G. New nematodes (Filariidae) from North American ruminants. Zoologischer Anzeiger, 1935, 110, 202-208.

YAGI K., Bain O. \& Shoho C. Onchocerca suzukii n. sp. and O. skrjabini (= O. tarsicola) from a relict bovid, Capricornis crispus, in Japan. Parasite, 1994, 1, 349-356.

Reçu le 26 février 2007 Accepté le 18 juin 2007 


\title{
The French Society of Parasitology is delighted to welcome in Paris the $\mathbf{X}^{\text {th }}$ European Multicolloquium of Parasitology "From satellites to microsatellites"
}

\author{
24-29 August 2008
}

Under the patronage of the European Federation of Parasitology

\begin{abstract}
EMOP X proposes a multidisciplinary approach to discuss the latest results on the role of parasites in sustainable interactions within ecosystems; on the considerable load of parasitic diseases on human and animal populations; on the most recent breakthroughs in prophylaxis and therapeutics ; and on the impact of global changes on parasitic systems.
\end{abstract}

\section{Provisional Scientific Program}

The program will include oral communications, posters and keynote lectures. These communications will be delivered during 70 sessions organised in the 15 following symposia:

1 - Apicomplexa

2 - Kinetoplastida

3 - Ectoparasites, vectors and control strategies

4 - Intestinal and liver parasites

5 - Blood and tissue metazoan infections

6 - Taxonomy, evolution and phylogeny

7 - Emergent and nosocomial infections

8 - Cellular and molecular biology

9 - Immunology

10 - Parasites of fishes and other ectothermic vertebrates

11 - Population genetic structure and molecular epidemiology

12 - Innovative epidemiology

13 - Innovative strategies in diagnosis

14 - Ethics, teaching and epistemology

15 - Innovative prevention strategies

\section{Satellite Symposia and Round Tables}

Round tables and workshops will be organized upon request to the organizers. Satellite symposia will be organized by industrial firms.

\section{Venue of the Multicolloquium}

EMOP X will be organized at the "Cité Universitaire de Paris". This campus is located in the middle of a nice park, nearby downtown Paris. The opening ceremony will be held in the "Grand amphithéatre" of the historical Sorbonne.

\section{EFP Young Scientist Award (YSA)}

The EFP will offer Young Scientist Awards to stimulate the participation of young parasitologists and thus to contribute to an increasing development of parasitology in Europe. Awards will be in two areas: "Research in basic parasitology" and "Research in applied parasitology". Up to three prizes may be awarded in each field. Details instructions on : www.emop10.eu

\section{Scholarships for Parasitologists}

Following the tradition, the EFP will offer a number of scholarships for young scientists to attend EMOP $\mathrm{X}$ in Paris. The French Society of Parasitology will also provide support for scientists not belonging to the EU and reduced registration fees will be available for students.

\section{Accommodation}

Low-cost accommodation will be available on the campus but conventional accommodation will be also organized in near-by hotels.

\section{Important dates}

Deadline for abstracts : 2 april 2008

Deadline for early registration : 2 may 2008

EMOP web site : www.emop10.eu

Registration, submission of abstracts, YSA, scholarships, accommodation and definitive program will be available through these regularly updated web pages.

\author{
Conference secretariat \\ EUROPA ORGANISATION \\ 38-40 avenue de New York, F-75016 Paris \\ Phone : $+33(0) 144315200$ \\ Fax : + $33(0) 144315201$ \\ E-mail : contact@emop10.eu
}

\section{EMOP X}

Honorary President

Jean-Antoine Rioux

European Federation of Parasitology

Executive board

President: Santiago Mas-Coma (Spain). Vice-Presidents: Fabrizio Bruschi (Italy) \& Yves Carlier (Belgium). Treasurer: Hans Sluiters (The Netherlands). Secretary: Jean Mariaux (Switzerland)

Members at large

Tor A. Bakke (Norway), Libuse Kolarova (Czech Republic), Kirill Galaktionov (Russia), Ewert Linder (Sweden) and Ermanno Candolfi (France)

\section{Local Organising Committee}

Board

Jean Dupouy-Camet (Coordinator), Gérard Duvallet, Daniel Camus, MarieLaure Dardé, Michel Franc, Jérôme Depaquit, Philippe Dorchies, René Houin, Gérard Luffau.

Members at large

Odile Bain, Marie-Hélène Bessières, Pascal Boireau, Ermanno Candolfi, Isabelle Desportes, Gilles Dreyfuss, Fabienne Girard, Patrick Giraudoux, Ronan Jambou, Jacques Le Bras, Philippe Loiseau, Hervé Pelloux, Isabelle Tardieux

International Organising Committee

Ziya Alkan (Turkish Society of Parasitology)

Carmen M. Cretu (Romanian Society of Parasitology)

Róbert Farkas (Hungarian Society of Parasitologists)

Vasil Golemansky (Bulgarian Society of Parasitology)

Stylianos Haralabidis (Greek Society of Parasitology)

Andrew Hemphill (Swiss Society of Parasitology)

Celia Holland (Irish Society of Parasitology)

Bretislav Koudela (Czech Society of Parasitology)

Charlotte Maddox-Hyttel (Scandinavian-Baltic Society of Parasitology \& Danish Society of Parasitology)

Maria-Teresa Manfredi (Italian Society of Parasitology)

Bozena Moskwa (Polish Society of Parasitology)

Kosta Y. Mumcuoglu (Israel Society of Parasitology)

Lali Murvanidze (Georgian Society of Parasitology)

Branislav Petíko (Slovak Society of Parasitology)

Lisa Ranford-Cartwright (British Society of Parasitology)

Henk Schallig (Netherlands Society of Parasitology)

Thomas Schnieder (German Society of Parasitology)

Peter Van den Bossche (Belgian Society of Parasitology)

International Scientific Committee

Eduardo Dei-Cas (Coordinator) and the chairs of the different symposia 